\title{
GENETIC EVIDENCE FOR WIDE DISTRIBUTION OF THE ALIEN PRAWN-GOBY, VANDERHORSTIA MERTENSI (ACTINOPTERYGII: PERCIFORMES: GOBIIDAE), ALONG THE NORTHEAST MEDITERRANEAN
}

\author{
Mehmet Baki YOKES ${ }^{1 *}$, Murat BILECENOGLU ${ }^{2}$, Menachem GOREN ${ }^{3}$, Bella S. GALIL ${ }^{4}$, \\ and Arik DIAMANT ${ }^{5}$
}

\author{
${ }^{1}$ Haliç University, Faculty of Arts and Sciences, Department of Molecular Biology and Genetics, Istanbul, Turkey \\ ${ }^{2}$ Adnan Menderes University, Faculty of Arts \& Sciences, Department of Biology, Aydin, Turkey \\ ${ }^{3}$ Department of Zoology, George S. Wise Faculty of Life Sciences, Tel Aviv University, Tel Aviv, Israel \\ ${ }^{4}$ National Institute of Oceanography, Israel Oceanographic and Limnological Research, Haifa, Israel \\ ${ }^{5}$ National Center for Mariculture, Israel Oceanographic and Limnological Research, Eilat, Israel
}

Yokes M.B., Bilecenoglu M., Goren M., Galil B.S., Diamant A. 2009. Genetic evidence for wide distribution of the alien prawn-goby, Vanderhorstia mertensi (Actinopterygii: Perciformes: Gobiidae), along the northeast Mediterranean. Acta Ichthyol. Piscat. 39 (2): 153-156.

\begin{abstract}
Vanderhorstia mertensi Klausewitz, 1974, is a recently acknowledged alien fish in the Mediterranean Sea, hitherto observed only from Fethiye Bay, Turkey. To explore its distribution, trawl bycatch from eastern Antalya and Iskenderun was examined and an underwater survey was performed off Kas (western Antalya). An established population was found off Güvercin Island, Kas, and six specimens were identified from trawl bycatch collected off Antalya and Iskenderun. The trawl-collected specimens were badly damaged and identification was made possible by the analysis of their $16 \mathrm{~S}$ rDNA sequences. Our findings suggest that the species was only recently introduced and its population size has increased rapidly. Symbiotic relationship with alpheids (Apheidae, Crustacea) may have enhanced this prawn-goby's establishment and dispersal along the Mediterranean coast of Turkey.
\end{abstract}

Keywords: Vanderhorstia mertensi, Gobiidae, alien species, 16S rDNA, Mediterranean Sea, Turkey

Gobiidae is the most species-rich family of marine fishes. The family is represented by more than 60 species in the Mediterranean Sea, four of which are aliens that have entered through the Suez Canal, i.e., Coryogalops ochetica (Norman, 1927), Oxyurichthys papuensis (Valenciennes, 1837), Favonigobius melanobranchus (Fowler, 1934), and Silhouettea aegyptia (Chabanaud, 1933) (see: Golani et al. 2006, Kovačić and Golani 2007). Recently, a dense population of the alien Mertens' prawngoby, Vanderhorstia mertensi Klausewitz, 1974, has been reported from Fethiye Bay (Turkey) (Bilecenoglu et al. 2008). Whereas the earlier aliens were first recorded in the Mediterranean in either Egypt or Israel, close to the opening of the Suez Canal, V. mertensi was first reported off Turkey. Ship-mediated introduction of this species has been suggested, however, considering its restricted habitat preference and mutualistic relations with alpheids (Alpheidae, Crustacea), it may also have entered through the Suez Canal like the previous introductions. If that is the case, there should be yet unnoticed populations of this species in the south-eastern Levant. In the framework of this study, an underwater survey for $V$. mertensi was performed along the coast of Kas-Kekova Special Environmental Protection Area (western Antalya) and bottom trawl bycatch from eastern Antalya and Iskenderun were examined to determine the spread of the species along the Mediterranean coasts of Turkey (Fig. 1).

Sample collection. In October 2008, an underwater survey was performed along the coasts of Kas (Antalya). Suitable habitats for $V$. mertensi populations were sought by SCUBA diving between $8-15 \mathrm{~m}$ depths. The number of observed specimens was counted, several individuals were photographed in their habitat, and one specimen was collected by hand net (Fig. 2).

Trawl samples from previous expeditions conducted on the eastern coasts of Antalya and Iskenderun in May-June 2008 were examined. Six badly damaged and previously unidentified prawn-goby specimens were chosen for DNA analysis. The specimens had been preserved in $70 \%$ ethanol and deposited in the Zoological Museum of Adnan Menderes University (ZMADU). Two specimens of $V$. mertensi from Fethiye were collected by

\footnotetext{
* Correspondence: Dr. Mehmet Baki Yokes, Haliç Üniversitesi, Moleküler Biyoloji ve Genetik Bölümü, Darulaceze Cd. No. 14 Okmeydani, 34384 Istanbul, Turkey, phone: 90212 2209696, fax: 90212 5303535, e-mail: bakiyokes@halic.edu.tr
} 
dredge for comparison (lat $36^{\circ} 41^{\prime} 00^{\prime \prime} \mathrm{N}$, long $\left.28^{\circ} 02^{\prime} 46^{\prime \prime} \mathrm{E}\right)$. Nine gobiid specimens of known identity, which have been previously deposited in ZMADU, were also included in the study for genetic analysis (Table 1).

Genetic analysis. DNA was extracted from $10 \mathrm{mg}$ of muscle tissue by using High Pure PCR Template Preparation Kit (Roche) according to the user manual. Mitochondrial 16S rDNA sequences were amplified from the isolated genomic DNA by PCR, using thermocycler (Techne TC-312). The PCR mixture included $50 \mathrm{ng}$ of genomic DNA, 1 unit of Taq Polymerase (Fermentas), dNTP mix (each $0.25 \mu \mathrm{M}$ ), reaction buffer with $2 \mathrm{mM}$ $\mathrm{MgCl}_{2}, 0.1 \mu \mathrm{M}$ each of the primers 16Sar-L (CGCCT-GTTTATCAAAAACAT) and 16Sbr-H (CCGGTCT-GAACTCAGATCACGT). The final volume was raised to $25 \mu \mathrm{L}$ by adding $\mathrm{ddH}_{2} \mathrm{O}$. PCR steps were as follows: initial denaturation at $95^{\circ} \mathrm{C}$ for $2 \mathrm{~min}$; 40 cycles of denaturation at $95^{\circ} \mathrm{C}$ for $1 \mathrm{~min}$; annealing at $50^{\circ} \mathrm{C}$ for $1 \mathrm{~min}$ and 30 $\mathrm{s}$; extension at $72^{\circ} \mathrm{C}$ for $2 \mathrm{~min}$. The PCR was completed with a final extension step at $72^{\circ} \mathrm{C}$ for $5 \mathrm{~min}$. After the amplification, the PCR products were checked on $1.5 \%$ agarose gel and purified using High Pure PCR Product Purification Kit (Roche) according to the user manual. Products were sequenced using 16Sbr-H primer (Macrogen Inc., Seoul, Korea). Nucleotide sequences were aligned automatically using MEGA version 3.1 (Kumar et al. 2004).

A population of Vanderhorstia mertensi was observed around Güvercin Island (Kas) during the SCUBA surveys (lat $36^{\circ} 11^{\prime} 29^{\prime \prime} \mathrm{N}, 29^{\circ} 36^{\prime} 36^{\prime \prime} \mathrm{E}$ ). More than 100 probable nest holes were recorded on approximately $500 \mathrm{~m}^{2}$ of muddy sandy sea bottom and 24 individuals were seen, six of which were in pairs. This result is comparable to the Fethiye Bay population of the Mertens' prawn-goby, where a maximum abundance of 7 individuals per $\mathrm{m}^{2}$ was reported (Bilecenoglu et al. 2008). The burrows were formed by a network of tunnels, most possibly dug by accompanying shrimp (Alpheus sp.); however no shrimp was observed. Five individuals of Vanderhorstia mertensi were photographed, but it was only possible to catch one voucher specimen.

Analysis of $16 \mathrm{~S}$ rDNA sequences showed that all of the six unidentified prawn-gobys had the identical sequence of Vanderhorstia mertensi specimens obtained from Fethiye.

It had been a surprise to find a population of this sandburrowing species on the westernmost coast of Turkey without previously being detected off the southern Levantine coast. It is possible that its habitat preference and timid habits prevented detection of southern populations. The badly damaged specimens in the trawl catches also suggest that past catches may have been discarded as unidentifiable material. The genetic examination shows that this species had already been established on both the eastern and western Mediterranean coasts of Turkey when it was first observed in Fethiye Bay, indicating that introduction via the Suez Canal is much more likely than through shipping. However, in the framework of a marine biodiversity project, the coasts of Kas, including Güvercin Island, have been regularly monitored between 2002 and 2007 and many alien species have been recorded in this particular area (Yokes et al. 2002, Yokes and Galil 2006a-c, Meriç et al. 2008). Within this period, the region about Güvercin Island was observed 24 times during SCUBA dives, most recently on 17 September 2007. During all of these dives, neither $V$. mertensi nor burrows of alpheids were observed. Our findings suggest that the introduction of $V$. mertensi to the region is a recent event, and that its populations increased rapidly. Symbiotic relationship with locally established native or alien alpheids

Gobiidae specimens investigated in this study

\begin{tabular}{lccc}
\hline Species & Location & Collection method & GenBank Accession \\
\hline Chromogobius zebratus & Fethiye & SCUBA diving & FJ460193 \\
Deltentosteus colonianus & Iskenderun & Trawl & FJ517537 \\
Gobius geniporus & Fethiye & SCUBA diving & FJ460200 \\
Lesueurigobius friesii & Iskenderun & Trawl & FJ460195 \\
Oxyurichthys papuensis & Iskenderun & Trawl & EU364559 \\
Pomatoschistus bathi & Bodrum & SCUBA diving & FJ460196 \\
Thorogobius macrolepis & Fethiye & SCUBA diving & FJ460194 \\
Vanderhorstia mertensi 715 & Fethiye & Dredge & FJ460188 \\
Vanderhorstia mertensi 716 & Fethiye & Dredge & FJ460189 \\
sample 717 & Antalya & Trawl & FJ460190 \\
sample 718 & Iskenderun & Trawl & FJ460191 \\
sample 722 & Iskenderun & Trawl & FJ517533 \\
sample 723 & Iskenderun & Trawl & FJ517534 \\
sample 724 & Antalya & Trawl & FJ517535 \\
sample 726 & Iskenderun & Trawl & FJ517536 \\
\hline
\end{tabular}




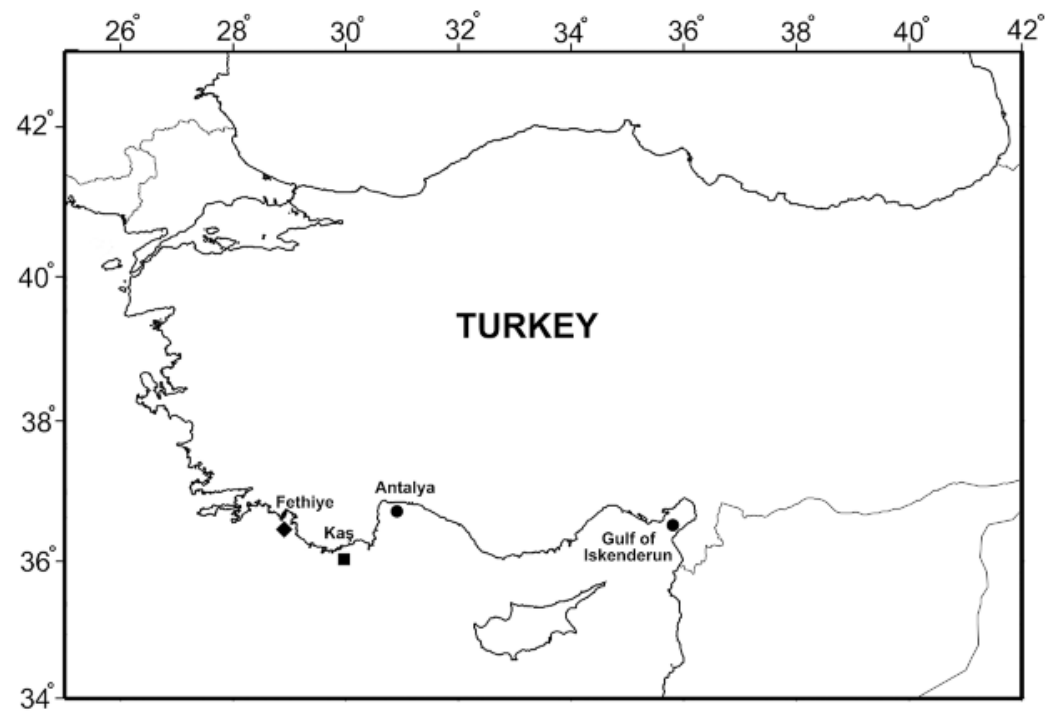

Fig. 1. Map of the study area; Legend: dredge site, $\square$ site of underwater survey, $\bullet$ trawling site

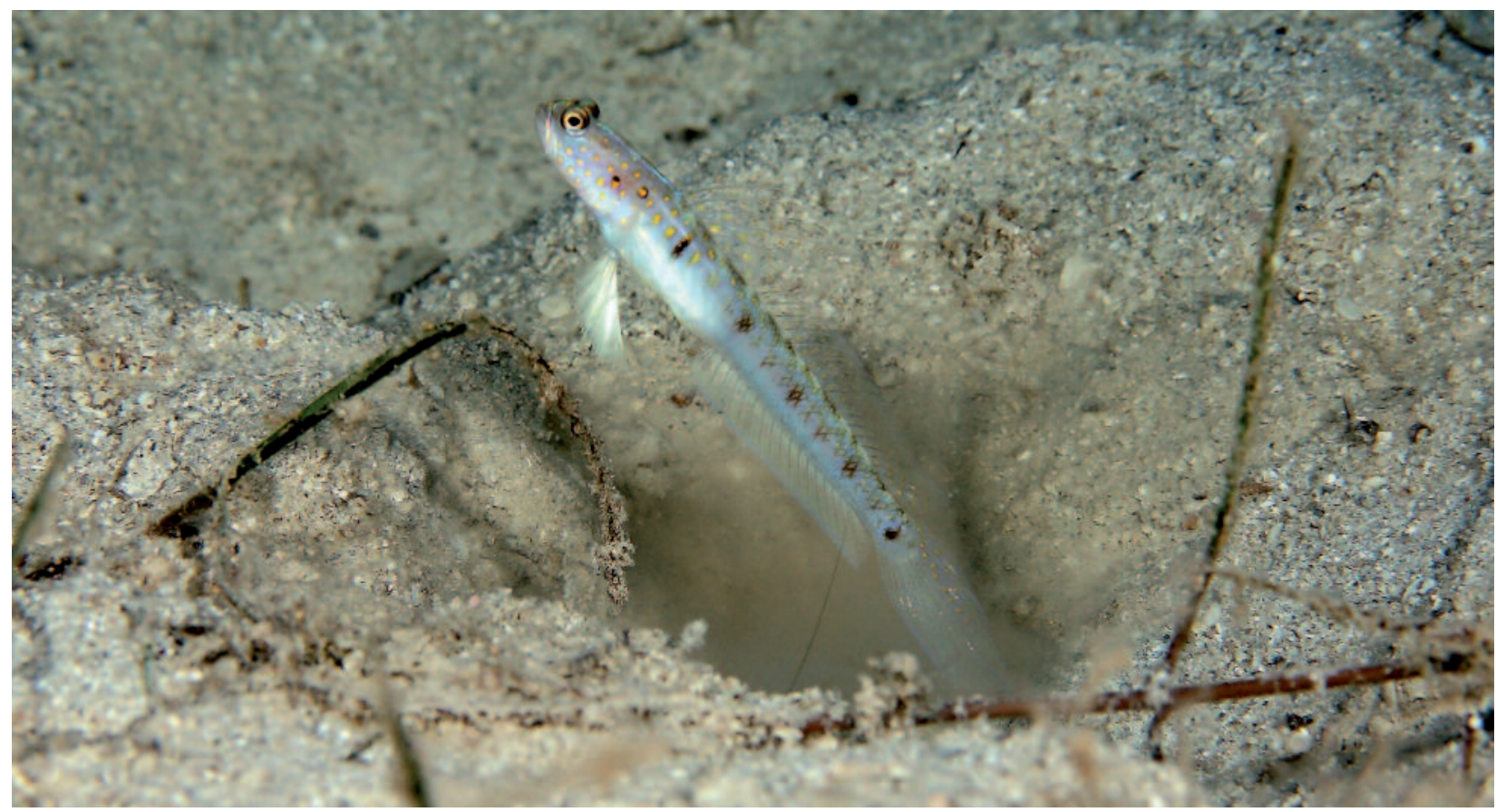

Fig. 2. Vanderhorstia mertensi individual hovering at the entrance of its burrow opening, Kas, Antalya

may play a role in facilitating the establishment and dispersal of the species along the Mediterranean coast of Turkey.

\section{ACKNOWLEDGEMENTS}

This research was partially supported by the Porter School of Environmental Studies at Tel Aviv University with funding from the Italian Ministry of the Environment, Land and Sea. We thank M. Gökoglu, K. Gayer, N. Stern, Y. Klopman, M. Cooper, E. Kalkan, U. Karhan, U. Tural, V. Demir, A. Balcı and H. Çolak for their invaluable help in the research, and $\mathrm{H}$. Yokes for underwater photography.

\section{REFERENCES}

Bilecenoglu M., Yokes M.B., Eryigit A. 2008. First record of
Vanderhorstia mertensi Klausewitz, 1974 (Pisces, Gobiidae) in the Mediterranean Sea. Aquatic Invasions 3: 475-478. DOI: 10.3391/ai.2008.3.4.21.

Golani D., Massuti E., Orsi-Relini L., Quignard J.-P. 2006. Gobiidae. In: CIESM Atlas of Exotic Fishes in the Mediterranean. http://www.ciesm.org/atlas/appendix1.html.

Kovačić M., Golani D. 2007. First record of Papillogobius melanobranchus in the Mediterranean Sea and new data on geographic distributions, bathymetric ranges and morphology of several small benthic fishes in the Levant. Cybium 31: 417-425.

Kumar S., Tamura K., Nei M. 2004. MEGA3: Integrated software for Molecular Evolutionary Genetics Analysis and sequence alignment. Briefings in Bioinformatics 5, $150-163$. 
Meriç E., Avsar N., Yokes M.B. 2008. Some alien foraminifers along the Aegean and southwestern coasts of Turkey. Micropaleontology 54: 307-349.

Yokes M.B., Dervisoglu R., Karacik B. 2002. Likya kiyilarinda denizel biyolojik zenginlik arastirmasi. [Marine biological richness assessment on the Lycian Coasts.] Pp. 166-181. In: 6. Sualti Bilim ve Teknoloji Toplantisi, 22-24 Kasim 2002, Istanbul. [Proceedings of SBT 2002-6th National Underwater Science and Technology Meeting, 22-24 November 2002, Istanbul.] [In Turkish.]

Yokes M.B., Galil B.S. 2006a. New records of alien decapods (Crustacea) from the Mediterranean Coast of Turkey, with a description of a new Palaemonid species. Zoosystema 28: 747-755.
Yokes M.B., Galil B.S. 2006b. The first record of the needlespined urchin Diadema setosum (Leske, 1778) (Echinodermata: Echinoidea: Diadematidae) from the Mediterranean Sea. Aquatic Invasions 1: 188-190. DOI: 10.3391/ai.2006.1.3.15.

Yokes M.B., Galil B.S. 2006c. Touchdown-first record of Percnon gibbesi (H. Milne Edwards, 1853) (Crustacea: Decapoda: Grapsidae) from the Levantine coast. Aquatic Invasions 1: 130-132. DOI: 10.3391/ai.2006.1.3.5.

Received: 16 February 2009

Accepted: 8 June 2009

Published electronically: 10 December 2009 